\title{
EFEKTIFITAS PENERAPAN STRATEGI ONLINE MARKETING OLEH UMKM DALAM MASA PEMBATASAN SOSIAL BERSKALA BESAR (PSBB) CORONA VIRUSES DISEASE 2019 (COVID-19)
}

\author{
Royan Jaluseta Anugrah \\ Universitas Islam Negeri Sunan Ampel \\ g93218099@uinsby.ac.id
}

\begin{abstract}
Indonesia is currently in an uproar by a dangerous virus called covid-19. Covid-19 is a virus that has a very fast transmission, so people must implement social restrictions in order to avoid covid-19 transmission. All activities that cause the crowd to do from home, including religious, economic, and educational activities. This greatly affects the daily habits of the people who are required to do online activities. The impact of covid19 was not only felt by the community, but also felt by MSME business people. Until 2018 the total number of MSME units totaled 64.2 million throughout Indonesia and MSME had a contribution of $60.3 \%$ of the total Gross Domestic Product (GDP) of Indonesia. To be able to maintain the stability of the Indonesian economy, MSME businesses are required to prepare strategies to minimize the impact of covid-19. By changing the concept of marketing to online and utilizing special programs from the Ministry of Cooperatives and SMEs, MSME businesses will be more effective in increasing their profits.
\end{abstract}

Keywords : COVID-19; MSME; Online Marketing.

\section{PENDAHULUAN}

Saat ini seluruh dunia telah memasuki era digital, dimana jaringan internet maupun teknologi informasi komputer sudah bisa diakses dimana-mana. Era digital sendiri adalah sebuah istilah yang digunakan untuk kemunculan sistem digital, jaringan internet, juga teknologi informasi komputer yang ada di seluruh dunia. ${ }^{1}$ Orang-orang saat ini sudah tidak asing lagi mengenai internet, mulai dari remaja hingga orang dewasa. Bahkan tidak sedikit anak-anak dibawah umur sudah bisa mengakses internet. Ini menandakan zaman yang sudah semakin canggih dan teknologi yang semakin maju. Dengan bermodalkan kuota internet, orang-orang bisa menemukan apa pun yang dia butuhkan. Mulai dari ilmu pengetahuan, informasi tentang negara tempat tinggalnya, bahkan hingga trik-trik khusus yang tidak pernah terbayangkan sebelumnya. Hal ini tentunya sangat membantu bagi masyarakat, selain untuk menambah wawasan, masyarakat juga tidak akan tertinggal oleh informasiinformasi menarik yang beredar saat ini. 
Dengan kemajuan teknologi saat ini, penggunaan internet semakin melambung tinggi. Khususnya, para generasi milenial yang bahkan tidak bisa meninggalkan teknologi digital di setiap harinya, baik itu untuk memenuhi kebutuhan sehari-hari hingga melakukan kegiatan bisnis. Saat ini, sudah bisa ditemui orang-orang yang melakukan bisnis berbagai di media sosial. Mulai dari menjual perlengkapan, accesoris handphone, hingga berbagai peralatan untuk kecantikan. Sebagian orang sudah bisa memanfaatkan teknologi digital untuk bertahan hidup dengan bisnis tersebut. Namun, tidak sedikit juga orang yang belum memahami terkait manfaat dari teknologi digital tersebut.

Menjalankan suatu bisnis tentunya tidak akan semudah membalikkan tangan. Berbagai risiko hingga ancaman selalu menanti di setiap harinya. Dengan perkembangan teknologi pada era digital, semakin banyak e-commerce yang muncul di Indonesia. E-commerce merupakan sebuah platform jual-beli yang bisa diakses masyarakat dengan menggunakan teknologi digital. ${ }^{2}$ Ini tentunya menjadi ancaman tersendiri bagi bisnis UMKM yang ada di Indonesia. Selain e-commerce bisa menjadikan kegiatan jual-beli lebih mudah, e-commerce juga menawarkan berbagai kategori produk kepada para customer nya. Hal ini membuat orang-orang lebih tertarik untuk berbelanja melalui e-commerce daripada harus berkeliling mencari produk yang diinginkan yang justru membuat tenaga semakin terkuras.

\section{METODE PENELITIAN}

Penelitian ini menggunakan metode deskriptif kualitatif, yaitu menggunakan studi pustaka atau literatur yang ada, dengan menggunakan jurnal, buku, dan web yang relevan dengan penelitian. Selanjutnya, data akan disusun dan dianalisis dengan pendekatan analisis deskriptif yang akan menghubungkan faktor-faktor tertentu dengan fenomena yang terjadi saat ini.

\section{PEMBAHASAN}

Penelitian terdahulu telah dilakukan analisa efektifitas pemasaran online dan juga implikasinya untuk bisnis Usaha Mikro, Kecil dan Menengah (UMKM). Penelitian tersebut diantaranya Pengaruh Strategi Pemasaran Online terhadap Peningkatan Laba UMKM, yang disusun oleh Ira Setiawati dan Penta Widyartati. Penelitian ini menggunakan metode kuantitatif dengan mengambil sampel pada perusahaan jasa, dagang, dan manufaktur yang telah menggunakan pemasaran online juga berskala UMKM di wilayah Jawa Tengah. Dari hasil penelitian disampaikan bahwa strategi pemasaran online berpengaruh terhadap peningkatan laba UMKM di Jawa Tengah. 
Penelitian yang dilakukan oleh Aknolt Kristian Pakpahan yaitu Covid-19 dan Implikasi bagi Usaha Mikro, Kecil, dan Menengah. Dari hasil penelitian ini situasi pandemi covid-19 memberikan tantangan sekaligus peluang bagi pelaku bisnis UMKM di Indonesia. ada beberapa solusi jangka pendek untuk mempertahankan eksistensi UMKM, yakni: protokol kesehatan ketat dalam menjalankan aktivitas ekonomi oleh UMKM, penundaan pembayaran hutang untuk menjaga likuiditas keuangan UMKM, bantuan keuangan bagi UMKM dan kebijakan struktural. Adapun cara untuk membantu UMKM ditengah pandemi covid-19 adalah dengan memanfaatkan dana Tanggung Jawab Sosial dan Lingkungan (TJSL) yang dimiliki oleh perusahaan swasta dan Badan Usaha Milik Negara (BUMN).

Penelitian lainnya dilakukan oleh Meri Nur Amelia dan kawan-kawan yaitu E-UMKM: Aplikasi Pemasaran Produk UMKM Berbasis Android Sebagai Strategi Meningkatkan Perekonomian Indonesia. Penelitian ini menggunakan metode deskriptif kualitatif dan analisis yang digunakan diperoleh dari wawancara dengan berbagai pemilik UMKM di Semarang. Dari hasil penelitian disampaikan bahwa konsep E-UMKM merupakan terobosan baru untuk memasarkan produk UMKM dalam menembus pasar bebas ASEAN. Dengan adanya E-UMKM diharapkan dapat membantu produsen UMKM Indonesia dalam memasarkan hasil produk mereka tidak hanya dalam negeri tetapi hingga ke luar negeri.

Dari beberapa penelitian terdahulu tersebut kami mencoba melakukan penelitian lanjutan dengan analisa efektifitas penerapan strategi online marketing oleh UMKM dalam masa PSBB COVID-19. Dengan menggunakan beberapa literatur pustaka yang relevan, kami akan melakukan analisis dengan metode deskriptif kualitatif.

\section{Konsep Pemasaran Online}

Cepatnya kemajuan teknologi yang terjadi saat ini menyebabkan pelaku bisnis harus melakukan penyesuaian-penyesuaian dengan cepat, baik dalam hal strategi maupun tujuan. Dengan teknologi saat ini tentunya memberikan dampak yang besar bagi para pelaku bisnis. Pendekatan produk dapat dilakukan dengan mudah dan cepat kepada para konsumen. Teknologi digital digunakan sebagai sarana untuk memasarkan dan menjual produk. Pemasaran merupakan suatu proses dan manajerial yang membuat individu atau kelompok mendapatkan apa yang diinginkan dan dibutuhkan dengan menciptakan, menawarkan, dan mempertukarkan produk yang bernilai kepada pihak lain atau segala kegiatan yang menyangkut penyampaian produk atau jasa mulai dari produsen sampai dengan konsumen. Sasaran dari pemasaran ini yaitu menarik pelanggan baru dengan menjanjikan nilai superior, menetapkan harga yang menarik, mendistribusikan produk atau jasa dengan mudah, mempromosikan secara efektif serta mempertahankan pelanggan yang sudah ada dengan tetap memegang 
prinsip yaitu kepuasan pelanggan. (Saifuddin, 2013). Pemasaran meliputi aktivitas yang berkaitan dengan penjualan, pengiklanan, promosi, serta penentuan harga. Pemasaran online merupakan segala aktivitas yang menyangkut kegiatan pemasaran suatu produk atau jasa dengan menggunakan atau melalui media online. Pemasaran online dapat mempermudah para pelaku bisnis untuk meningkatkan laba, namun pemasaran tidak bisa menghindari tiga komponen yang selalu menyertai, yaitu kompetitor, konsumen dan perusahaan. Pelaku bisnis yang paham akan manfaat dari pemasaran online akan menggunakannya untuk berkomunikasi, mencari konsumen, dan menjual produknya. Menurut Saifuddin (2020) Pemasaran digital adalah sebuah penggunaan teknologi elektronik terutama dalam bentuk teknologi informasi untuk melakukan segala proses bisnis termasuk didalamnya kegiatan jual beli produk, jasa dan informasi, meningkatkan permintaan, melayani pelanggan dengan sentuhan digital.

\section{Usaha Mikro, Kecil dan Menengah (UMKM)}

Undang-Undang No. 20 Tahun 2008, mendefinisikan UMKM sebagai Usaha produktif milik orang perorang dan atau badan usaha perorangan yang memenuhi kriteria usaha mikro, memiliki kekayaan bersih paling banyak Rp. 50.000.000 (lima puluh juta rupiah) tidak termasuk tanah dan bangunan tempat usaha atau memiliki hasil penjualan tahunan paling banyak Rp. 300.000.000 (tiga ratus juta rupiah). Adapun tujuan dari UMKM adalah menumbuhkan dan mengembangkan usahanya dalam rangka meningkatkan perekonomian nasional.

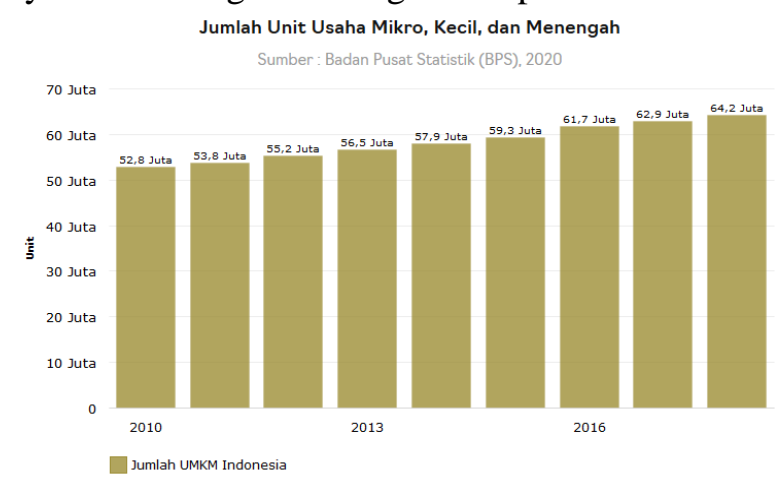

Berdasarkan Badan Pusat Statistik (BPS) hingga tahun 2018 total unit UMKM berjumlah 64,2 juta di seluruh Indonesia. Pada tahun 2020 Kementrian Komunikasi dan Informatika (Kominfo) telah mencatat sebanyak 9,4 juta UMKM sudah Go online dalam memasarkan produknya. Artinya masih ada sekitar 54,8 juta UMKM yang belum bisa memanfaatkan media online untuk memasarkan produknya. Kementrian Koperasi dan UKM telah mengadakan sebuah program bersama para pelaku e-commerce yang diharapkan 
bisa mempercepat transformasi UMKM di Indonesia menuju digital. Namun, tantangan bagi para pelaku bisnis UMKM saat ini adalah bagaimana memenangkan pangsa pasar dengan mengoptimalkan, mengelola, dan menentukan strategi pemasaran ditengah pandemi virus corona. UMKM menjadi pelaku bisnis yang terdampak signifikan dengan adanya penyebaran wabah virus corona. Hal tersebut disebabkan, UMKM memiliki kontribusi sebesar 60,3\% dari total Produk Domestik Bruto (PBD) Indonesia. ${ }^{4}$

\section{Corona Viruses Disease (COVID-19)}

Pada bulan Desember tahun 2019, sebuah virus baru muncul di permukaan bumi. Berawal dari Wuhan, Cina. World Health Organization (WHO) menjelaskan bahwa Coronaviruses (Cov) adalah virus yang menginfeksi sistem pernapasan. Infeksi virus ini disebut COVID-19. Penyebaran virus ini sangat cepat, bahkan saat ini penyebarannya sudah mencapai lintas negara. Sampai saat ini terdapat 188 negara yang telah mengkonfirmasi terkena virus Corona. ${ }^{5}$ Termasuk salah satunya adalah Negara Indonesia.

Saat ini virus corona menjadi pusat perhatian di seluruh belahan dunia. Tidak sedikit perekonomian negara yang terdampak atas wabah virus tersebut. Dengan bertambahnya pasien di setiap harinya, beberapa negara bahkan telah memberlakukan peraturan untuk pembatasan aktivitas atau dikenal dengan istilah lockdown. Beberapa Gubernur di Indonesia juga telah memberlakukan peraturan tersebut, yang diistilahkan dengan Pembatasan Sosial Berskala Besar (PSBB) guna mencegah bertambahnya pasien virus corona. PSBB merupakan sebuah peraturan untuk membatasi dan mengatur semua yang terkait dengan kegiatan perekonomian, sosial, budaya, keagamaan, dan pendidikan untuk mencegah penyebaran covid-19.

Sesuai dengan Undang-Undang Nomor 6 Tahun 2018 Tentang Kekarantinaan Kesehatan. Dalam UU nomor 6 tahun 2018 tentang Kekarantinaan Kesehatan Pasal 59 ayat (1) disebutkan; PSBB merupakan respon dari kedaruratan kesehatan masyarakat, sedangkan ayat (2) berbunyi; PSBB bertujuan mencegah meluasnya penyebaran penyakit kedaruratan kesehatan masyarakat yang terjadi antar orang di suatu wilayah tertentu. Dengan diberlakukannya PSBB tersebut diharapkan dapat memutus rantai penyebaran virus corona, sehingga masyarakat dapat beraktifitas seperti sedia kala dan perekonomian negara juga pulih kembali.

\section{Efektifitas Online Marketing}

Efektifitas adalah suatu ukuran yang menyatakan seberapa jauh target (kuantitas, kualitas, dan waktu) yang telah dicapai oleh manajemen, yang mana target tersebut sudah ditentukan terlebih dahulu. 
Saat ini telah banyak perusahaan yang memilih media online sebagai metode pemasarannya. Beberapa media yang sering digunakan adalah facebook, twitter, instagram, dan lain-lain. Dengan menggunakan media tersebut perusahaan akan bisa mencapai target pasar mereka. Beberapa fitur telah disediakan di dalam media tersebut, mulai dari penyedia jasa, kebutuhan sehari-hari, juga informasi-informasi terkini di seluruh negeri. Sehingga masyarakat ataupun generasi milenial khususnya lebih memilih media tersebut sebagai pengisi waktu luang mereka.

Dengan memanfaatkan media sosial, masyarakat bisa menambah wawasan terkait pengetahuan yang mereka tekuni tanpa membuang banyak waktu. Banyak perusahaan yang memanfaatkan hal ini untuk memasarkan produk yang mereka jual. Dengan kecenderungan masyarakat yang lebih memilih menghabiskan waktu dengan menggeluti media sosial, perusahaan akan dengan mudah mencapai target yang mereka tentukan.

Beberapa penelitian diantaranya dilakukan oleh Ira Setiawati dan Penta Widyartati. Penelitian tersebut dilakukan untuk menguji pengaruh strategi pemasaran online terhadap peningkatan laba UMKM. Dari hasil penelitian ini menunjukkan bahwa strategi pemasaran online berpengaruh positif terhadap laba UMKM di Jawa Tengah. Uji t dilakukan secara parsial dalam pengujian hipotesis untuk mengetahui ada tidaknya pengaruh variabel independen secara individu terhadap variabel dependen.Penelitian lainnya juga dilakukan oleh Swasta Priambada, yang berjudul Manfaat Penggunaan Media Sosial pada Usaha Kecil Menengah (UKM). Dari hasil penelitian tersebut para pelaku UKM telah menggunakan media sosial dalam proses komunikasi. Media sosial yang paling banyak digunakan adalah E-mail, web blog, dan facebook. Media sosial merupakan sarana komunikasi yang efektif, dengan sarana tersebut para pelaku UKM dapat meningkatkan pangsa pasar serta membantu keputusan bisnis. Dengan penggunaan media sosial dan melakukan update informasi di setiap harinya, para pelaku UKM dapat meningkatkan volume penjualan hingga lebih dari $100 \%$.

Sedangkan penelitian yang lain dilakukan oleh Khabib Alia Akhmad dengan judul Pemanfaatan Media Sosial bagi Pengembangan Pemasaran UMKM (Studi Deskriptif Kualitatif pada Distro di Kota Surakarta. Dari hasil penelitian tersebut pemanfaatan media sosial yang paling banyak digunakan adalah facebook, twitter, dan instagram. Penggunaan website bagi para pengelola distro terbilang sangat kecil, dikarenakan dibutuhkan biaya yang cukup besar untuk pengoperasian website sehingga dapat mengurangi keuntungan para pengelola distro. Para pemilik dan pengelola distro menyatakan bahwa untuk melakukan pemasaran secara konvensional seperti iklan di media massa dan media elektronik memerlukan biaya yang besar sehingga mereka lebih memilih melakukan pemasaran dengan memanfaatkan 
media sosial. Dengan media sosial, pemilik usaha dapat melakukan komunikasi, melalui komentar saran dan tanggapan dari para pelanggan dan dapat menjadikan komentar tersebut menjadi bahan evaluasi perusahaan untuk kedepannya.

Dengan menggunakan media sosial, para pelaku UMKM dapat meningkatkan penjualan mereka. Selain memperoleh keuntungan yang lebih, mereka juga dapat lebih intens untuk melakukan komunikasi dengan para pelanggan. Sehingga, dengan kritik dan saran yang disampaikan para pelanggan, pelaku UMKM dapat mengembangkan bisnis yang mereka jalankan. Komunikasi ini penting karena selain kita dapat mendapatkan saran dan masukan dari pelanggan, kita juga dapat mengetahui keinginan dari para pelanggan hingga perkembangan dari para kompetitornya.

\section{Online Marketing dalam Masa Pembatasan Sosial Berskala Besar (PSBB)}

Pemasaran online sangat berdampak positif bagi para pelaku UMKM. Selain untuk mengembangkan usaha, para pelaku UMKM juga dapat menganalisa strategi yang dilakukan untuk menghadapi para kompetitornya. Bahkan dapat meningkatkan penjualan dari produk yang mereka jual. Beberapa penelitian telah dilakukan terkait dampak dari wabah covid-19, diantaranya dilakukan oleh Silpa Hanoatubun, yang berjudul Dampak Covid-19 terhadap Perekonomian Indonesia. Dari hasil penelitian, intervensi kuat (PSBB) untuk meminimalisasi penyebaran covid-19 dapat menurunkan perekonomian lebih parah dibandingkan skenario minimal intervension. Akan tetapi, dalam konteks jangka panjang jika skenario yang terjadi adalah minimal intervension justru pertumbuhan ekonomi akan lebih tertekan. Dapat disimpulkan bahwa penggunaan strategi intervensi kuat mengalami kerugian ekonomi lebih rendah dibandingkan dengan skenario minimal intervension.

Penelitian lainnya dilakukan oleh Aknolt Kristian Pakpaham, dengan judul Covid-19 dan Implikasi bagi Usaha Mikro, Kecil, dan Menengah. Dari hasil penelitian ini Pembatasan Sosial Berskala Besar memberikan dampak yang sangat serius bagi para pelaku UMKM. Laporan terkait penurunan penjualan, permasalahan aspek pembiayaan, masalah distribusi barang, dan kesulitan mendapatkan bahan baku mentah dari sekitar 37.000 pelaku UMKM telah dilaporkan kepada Kementrian Koperasi dan UKM. Dengan adanya PSBB, ditakutkan aktivitas ekonomi terutama produksi, distribusi, dan penjualan akan mengalami gangguan yang akan berdampak semakin dalam pada kinerja UMKM dan perekonomian nasional. Dalam masa PSBB, semua sektor perekonomian merasakan dampaknya dan mengalami penurunan penjualan. Para pelaku usaha mengalami penurunan kinerja, yang berdampak tidak sedikit tenaga kerja yang dirumahkan. Hal tersebut tentunya akan 
membatasi pengeluaran masyarakat dan beberapa malah melakukan penyimpanan biaya. Dengan kehilangan pendapatannya, tingkat konsumsi dan daya beli masyarakat terhadap suatu produk juga akan mengalami penurunan.

Menteri Koperasi dan UKM mempersiapkan 8 program khusus untuk meredam dampak covid-19 bagi sektor koperasi dan UMKM. ${ }^{7}$ Antara lain:

1. Mengajukan stimulus daya beli produk UMKM dan koperasi.

2. Mendukung dan mengefektifkan social distancing tapi dalam waktu bersamaan juga warung- warung bisa berjalan dengan baik usahanya.

3. Program restrukturisasi dan subsidi suku bunga kredit usaha mikro.

4. Restrukturisasi kredit khusus bagi koperasi melalui LPDB KUMKM.

5. Mendorong penyediaan masker bagi tenaga medis maupun masyarakat umum.

6. Memasukkan sektor mikro dalam klaster penerima kartu pra kerja untuk pekerja harian.

7. Bantuan langsung tunai.

8. Mengusulkan $\mathrm{Pph} 21$, pajak penghasilan impor, Pph 25, restitusi pertambahan nilai bisa direlaksasi untuk KUMKM.

Dengan adanya program khusus dari Menteri Koperasi dan UKM, diharapkan para pelaku KUMKM dapat membawa dampak ekonomi positif. Para pelaku usaha dapat memanfaatkan program tersebut dan meminimalisir dampak dari PSBB. Selain itu, para pelaku bisnis UMKM dapat melihat kebutuhan pokok yang saat ini diprioritaskan oleh masyarakat, sehingga dengan produk kebutuhan pokok tersebut dapat memudahkan masyarakat juga menghasilkan keuntungan bagi para pelaku usaha. Dengan penghematan biaya yang dilakukan masyarakat dan memfokuskan untuk mendauhulukan membeli kebutuhan-kebutuhan pokok, hal ini dapat membawa keuntungan tersendiri bari para pelaku bisnis UMKM.

Sebuah penelitian dilakukan oleh Meri Nur Amelia dan kawan-kawan yaitu E-UMKM: Aplikasi Pemasaran Produk UMKM Berbasis Android Sebagai Strategi Meningkatkan Perekonomian Indonesia. Dari hasil penelitian ini konsep E-UMKM merupakan terobosan baru untuk memasarkan produk UMKM dalam menembus pasar bebas ASEAN. Dengan adanya E-UMKM diharapkan dapat membantu produsen UMKM di Indonesia dalam memasarkan hasil produk mereka tidak hanya dalam negeri tetapi hingga ke luar negeri. Dengan diterapkannya aturan tentang PSBB, para pelaku bisnis UMKM tentunya juga mengalami masalah tersendiri untuk memasarkan produk mereka. Dengan adanya konsep pemasaran online berupa aplikasi android tersebut dapat memudahkan para pelaku bisnis UMKM untuk mencapai target pangsa pasar yang telah mereka tentukan. Dilihat dari sisi konsumen, konsep E-UMKM ini juga memudahkan para konsumen untuk mencari produk yang mereka butuhkan, lebih praktis, dan tentunya tidak memerlukan banyak tenaga. 
Dengan membuat produk sesuai kebutuhan masyarakat saat ini dan juga menerapkan konsep E- UMKM tentunya dapat mencapai target yang maksimal bagi para pelaku bisnis UMKM. Produk yang dijual dalam aplikasi ini juga tentunya harus diuji dan mendapatkan izin terlebih dahulu dari pemerintah. Agar kualitas produk yang dijual terjamin dan tidak mengecewakan para konsumen. Konsep E-UMKM ini membawa keuntungan bagi kedua belah pihak, baik produsen maupun konsumen, sehingga pemasaran online yang dilakukan oleh para pelaku bisnis UMKM bisa berjalan lebih efektif.

\section{KESIMPULAN}

Cepatnya kemajuan teknologi yang terjadi saat ini menyebabkan pelaku bisnis harus melakukan penyesuaian-penyesuaian dengan cepat, baik dalam hal strategi maupun tujuan. Dengan teknologi saat ini tentunya memberikan dampak yang besar bagi para pelaku bisnis.

Berdasarkan Badan Pusat Statistik (BPS) hingga tahun 2018 total unit UMKM berjumlah 64,2 juta di seluruh Indonesia. Pada tahun 2020 Kementrian Komunikasi dan Informatika (Kominfo) telah mencatat sebanyak 9,4 juta UMKM sudah Go online dalam memasarkan produknya. Artinya masih ada sekitar 54,8 juta UMKM yang belum bisa memanfaatkan media online untuk memasarkan produknya. Dengan memanfaatkan media sosial, masyarakat bisa menambah wawasan terkait pengetahuan yang mereka tekuni tanpa membuang banyak waktu. Banyak perusahaan yang memanfaatkan hal ini untuk memasarkan produk yang mereka jual. Dengan kecenderungan masyarakat yang lebih memilih menghabiskan waktu dengan menggeluti media sosial, perusahaan akan dengan mudah mencapai target yang mereka tentukan. Dengan menggunakan media sosial, para pelaku UMKM dapat meningkatkan penjualan mereka. Selain memperoleh keuntungan yang lebih, mereka juga dapat lebih intens untuk melakukan komunikasi dengan para pelanggan.

Diberlakukannya PSBB dalam rangka memutus rantai penyebaran covid-19 ditakutkan aktivitas akan berdampak semakin dalam pada kinerja UMKM dan perekonomian nasional. Namun, dengan adanya program khusus dari Menteri Koperasi dan UKM, diharapkan para pelaku KUMKM dapat membawa dampak ekonomi positif. Para pelaku usaha dapat memanfaatkan program tersebut dan meminimalisir dampak dari PSBB. Selain menerapkan program tersebut, konsep E-UMKM juga membawa keuntungan bagi kedua belah pihak, baik produsen maupun konsumen, sehingga pemasaran online yang dilakukan oleh para pelaku bisnis UMKM bisa berjalan lebih efektif. 


\section{DAFTAR PUSTAKA}

Akhmad, Khabib Alia. (2015). Pemanfaatan Media Sosial bagi Pengembangan Pemasaran UMKM (Studi Deskriptif Kualitatif pada Distro di Kota Surakarta). Jurnal Duta.com. 9(1).

Amelia, Meri Nur, Yulianto Eko Prasetyo dan Iswara Maharani. (2017). EUMKM: Aplikasi Pemasaran Produk UMKM Berbasis Android Sebagai Strategi Meningkatkan Perekonomian Indonesia. Jurnal Prosiding Statif ke4.

Hanoatubun, Silpa. (2020). Dampak COVID-19 Terhadap Perekonomian Indonesia. Journal of EduPsyCouns. 2(1): 147.

Jayani, Dwi Hadya. (2020). Pemerintah Beri Stimulus, Berapa Jumlah UMKM di Indonesia?. databooks.katadata.co.id. (https://databooks.katadata.co.id/datapublish/2020/04/08/pemerintahberi-stimulus-berapa- jumlah-umkm-di-indonesia, diakses pada tanggal 9 Mei 2020).

Pakpahan, Aknolt Kristian. (2020). Covid-19 dan Implikasi bagi Usaha Mikro, Kecil, dan Menengah. Jurnal Universitas Katolik Parahyangan, Indonesia.

Priambada, Swasta. (2015). Manfaat Penggunaan Media Sosial pada Usaha Kecil Menengah (UKM). Jurnal Seminar Nasional Sistem Informasi Indonesia.

Saifuddin, M. (2013). Pengaruh Jenis Endorser dan Brand Name terhadap Sikap Atas Iklan, Sikap Atas Merk dan Niat Pembelian pada Produk High dan Low Involvement. Jurnal Ekonomi dan Bisnis Airlangga (JEBA), 23(3).

Saifuddin, M. (2020). Strategi Peningkatan Ekonomi Lembaga Sosial Dengan Memanfaatkan Aplikasi Pemasaran Berbasis Android (Studi kasus pada unit bisnis kidpreneuer di Yayasan AL MADINA Surabaya).

Sari, Fitriana Monica. (2019). Dunia Serba Digital, Ini 7 Fakta Menariknya. liputan6.com. (https://m.liputan6.com/bisnis/read/3928604/dunia-serbadigital-ini-7-fakta-menariknya, diakses pada tanggal 7 Mei 2020).

Setiawati, Ira dan Penta Widyartati. (2017). Pengaruh Strategi Pemasaran Online Terhadap Peningkatan Laba UMKM. Jurnal BIMA. Pascasarjana (S2) STIE Dharmaputra Semarang: 344.

Suripto, Teguh. (2018). Kajian Literatur Efektifitas Pemasaran Produk dengan Menggunakan Sistem Online Marketing di Era Disruption. Jurnal Ekonomi Syariah Indonesia. 8(2): 120- 128. 
Santia, Tira. (2020). 8 Program Antisipasi Dampak Covid-19 buat pelaku KUMKM. Liputan6.com. (https://m.liputan6.com/bisnis/read/4218795/8program-antisipasi-dampak-covid-19-buat-

pelaku-kumkm, diakses pada tanggal 16 Mei 2020).

Undang-Undang Republik Indonesia Nomor 20 Tahun 2008 Tentang Usaha Mikro, Kecil, dan Menengah.

Undang-Undang Republik Indonesia Nomor 6 Tahun 2018 Tentang Kekarantinaan Kesehatan. 